\title{
Emotions theory in Nietzsche: beyond traditional \\ Dualism
}

\author{
Teoria das emoções em Nietzsche: Além do dualismo
}

tradicional

Daniel Calbinoa

\begin{abstract}
In recent years there has been the advance of theories aimed at broadening the reflection on emotions and influences on moral aspects. In the midst of this discussion, the essay aims to investigate Nietzsche's philosophical for the critique of the reason versus emotion. As results, it is pointed out that Nietzsche preceded empirical psychology in centuries. If studies in the field of neuroscience bring inferences from explanations of physiology in the rational, Nietzsche pointed out to these hypotheses, although by purely logical and rational means. In short, the innovations in the author's thinking contribute to dialogue with the emotion's theory, as well as to counteract the ethical rationality superimposed on affects.
\end{abstract}

Keywords: Nietzsche. Reason. Emotions. Morality.

\section{Resumo}

Recentemente, tem-se observado um avanço de teorias destinadas a ampliar a reflexão sobre as emoções e suas influências sobre os aspectos morais. No bojo desta discussão, o ensaio tem como objetivo investigar a filosofia de Nietzsche enquanto crítica ao dualismo razão versus emoção. Enquanto resultados, destaca-se que Nietzsche precedeu em séculos a psicologia empírica. Se os estudos no campo da neurociência trazem inferências das explicações da fisiologia no racional, Nietzsche apontou para essas hipóteses, embora por meios puramente lógicos e racionais. Em resumo, as inovações no pensamento do autor contribuem para o diálogo com a teoria das emoções, bem como para contrapor a racionalidade ética sobreposta aos afetos.

Palavras-chave: Nietzsche. Razão. Emoções. Moralidade.

\footnotetext{
a Universidade de São João del Rei, Sete Lagoas, Minas Gerais, Brasil. Doutor em Administração, e-mail: dcalbino@ufsj.edu.br
} 


\section{Introduction}

For millennia, emotion has been analyzed as opposed to reason, being a reason one of the finest human capacities and completely independent of emotions (ARAUJO, 2001. In the history of philosophy, the relationship between reason and emotion has been a philosophical problem since the Greeks, and whose influence on Greek-Roman and Judeo-Christian culture has impaired knowledge of emotions theory (ALMADA, 2010; 2011).

The neglect of emotions was greatly enhanced by the unfolding of the Cartesian paradigm, which advocated the tendency to dichotomy body/mind, matter/spirit, reason/emotion, substantially affecting modern scientific thinking (COSTA; PASCUAL, 2012).

The primacy of reason is a hypothesis that justifies its hegemony not only in traditional philosophical thinking, but also in the field of neuroscience that has privileged cognitive thinking processes of behavior throughout the twentieth century, attributing to the emotions unrelated aspects of brain activity and social (ALMADA, 2010; MARIN; SILVEIRA, 2017).

Despite the strong dualistic ontological bias in the epistemology field, in recent years there has been a growing interest in the study of emotions by researchers from different fields (MARIN; SILVEIRA, 2017). The growing discoveries about emotions from the cognitive sciences, researchers in particular tied to an experimental view have brought new insights into metaethics, political philosophy, and epistemology (MARIN; SILVEIRA, 2017).

Araujo (2001) reports Antonio Damásio and Sacks's studies conducted from individuals with neurological injuries, showing how emotion integrates the processes of reasoning and decision making. Similarly, Almada (2010) emphasizes Gray's et al (2002) studies which emotional states selectively neural influence activity that relates to cognition in the prefrontal cortex, establishing a strong integration between emotion and reason. Borges (2017) also illustrates Prinz's studies in empirical psychology that indicate moral concepts are linked to emotional responses, even though they lack further criticism and reflection (ALVES, 2013).

Despite recent empirical contributions to question, the thesis between reason versus emotion, separating in their ontologies the extent of thought, these criticisms 
seem to have their roots and philosophical foundations in Frederick Nietzsche's works.

In the Birth of Tragedy, Nietzsche points out that there was no dualism in the pre-Socratic Greek philosophers, for they maintained an ontological balance between the metaphors in the Gods Dionysus (passion) and Apollo (reason). For Nietzsche, however, in Socrates' annihilation of Dionysus, a dictatorship of reason was established, and the supposed control of emotions by virtuous subjects.

In Twilight of the Idols, Nietzsche maintains that Socrates not only legitimizes dualism, but also establishes an equation based on the tyranny of reason through the idea of "reason $=$ virtue $=$ happiness". Beyond the critique of dualism, Nietzsche advances in the reflection where Socrates' emotions (his feeling of revenge against the nobility) will legitimize the creation of dialectics as the philosopher's moral. Nietzsche seems to anticipate the hypotheses of neuroscience studies that deal with the interference of emotions in the constitution of cognition (reason).

Not least in Ecce Homo, when commenting on the central ideas of his text, The Birth of Tragedy, he claims to be the first philosopher to include the dichotomy reason and emotion and their influence on the constitution of moral judgments:

\begin{abstract}
I had for my own inmost experience discovered the only symbol and counterpart of history, I had just thereby been the first to grasp the wonderful phenomenon of the Dionysian. And again, through my diagnosing Socrates as a decadent, I had given a wholly unequivocal proof of how little risk the trustworthiness of my psychological grasp would run of being weakened by some moralistic idiosyncrasy: to view morality itself as a symptom of decadence is an innovation, a novelty of the first rank in the history of knowledge. How far I had leaped in either case beyond the smug shallowpate-gossip of optimism contra pessimism! I was the first to see the intrinsic antithesis: here, the degenerating instinct which, with subterranean vindictiveness, turns against life, and there, a formula of highest affirmation, born of fullness and overfullness, a yea-saying without reserve to suffering self, to guilt self, to all that is questionable and strange in existence itself (NIETZSCHE, S2, 1872).
\end{abstract}

In order to deepen the arguments that overcome the dualism between reason and emotion, the guiding questions of this essay are: What are Nietzsche's philosophical bases for the critique of the reason and emotion dichotomy? What implications of the constitution of emotions in the cognitive plane of reason?

As a contribution, it is noteworthy that a bibliographic survey in the Capes journals of the last quadrennium (2013-2016) in the national philosophy journals classified in extract A1, A2, B1 and B2, it was observed that despite the increase in the number of works aimed to discuss the theories of emotions, however, there were only four articles (MARTINS, 2000; VIESENTEIR, 2010; ARALDI, 2015; LEITER; 
2017) that dialogue with Nietzsche's ideas, however, has no central axis to the dimensions of reason and emotion in the author's works.

Similarly, when reviewing the dissertations and thesis available in the collection of the Brazilian Digital Library of Theses and Dissertations, despite Nietzsche's popularity as an object of study (there were 220 papers discussing the author's thinking), however, only two discussed "en passant" the theme (MOREIRA, 2009; OLEARE, 2011), without delving into the relationships and inferences of emotions in the constitution of reason in Nietsche's thought.

In this sense, bringing Nietzsche's philosophical thinking to the field thus opens room not only for dialogue with a theme of interdisciplinary interest and interaction but it is also necessary to foster deeper discussions among theorists, especially on philosophical issues that permeate the theme of emotions study (MARIN; SILVEIRA, 2017).

\section{Genealogy of reason and emotion in Nietzsche}

Nietzsche in the Birth of Tragedy establishes a genealogy of the hegemonic discourse of reason, pointing out that before Socrates, in Greek tragedy, one did not think of a triumph of the abstract world of thought. For him, Apollo, the God of Clarity, Harmony and Order, and Dionysus, the God of Exuberance, of the disorder of music, were complementary to each other.

In his posthumous book, The Will to Power, Nietzsche illustrates how the dimensions of reason and emotion in ancient Greek thought maintained a constant tension in the figures of Dionysus and Apollo:

\footnotetext{
This antithesis of the Dionysian and the Apollinian within the Greek soul is one of the great riddles to which I felt myself drawn when considering the nature of the Greeks. Fundamentally I was concerned with nothing except to guess why precisely Greek Apollinianism had to grow out of a Dionysian subsoil; why the Dionysian Greek needed to become Apollinian; that is, to break his will to the terrible, multifarious, uncertain, frightful, upon a will to measure, to simplicity, to submission to rule and concept. The immoderate, disorderly Asiatic lies at his roots: the bravery of the Greek consists in his struggle with his Asiaticism; beauty is not given to him, as little as is logic or the naturalness of customs-it is conquered, willed, won by struggle: It is his Victory (NIEZTSCHE, S1050, BOOK IV, March- June, 1888).
}

Ferez (1999), when analyzing the main concepts of Nietzsche's thought, approaches that the existence of two Gods that represented the assumptions of reason (Apollo) and emotions (Dionysus) gave the perfect reconciliation of the 
drunkenness and form of the time. In the period, the separation between the citizen and the politician, the poet and the philosopher, Eros and Logos was not maintained.

However, the rupture begins with Socrates, who in using dialectics established a tyrannical reason for dominating contradictory instincts. Commenting on his own work - The Birth of Tragedy - in the book Ecce Homo, Nietzsche makes a point of emphasizing these dimensions as contributions to the area:

The Birth of Tragedy is a book quite strange to its age: no one would dream that it was begun in
the thunder of the battle of Wörth. I thought out these problems on cold September nights beneath
the walls of Metz. [...] the antagonism of the two concepts Dionysian and Apollonian - is translated
into metaphysics; history itself is depicted as the development of this idea; in tragedy this antithesis
has become unity; from this standpoint things which theretofore had never been face to face are
suddenly confronted, and understood and illuminated by each other... The two decisive innovations
in the book are, first, the comprehension of the Dionysian phenomenon among the Greeks - it
provides the first psychological analysis of this phenomenon, and sees in it the single root of all
Greek art; and, secondly, the comprehension of Socraticism - Socrates being presented for the first
time as the instrument of Greek dissolution, as a typical decadent. "Reason" versus Instinct.
"Reason" at any cost, as a dangerous, life-undermining force (NIETZSCHE, S1, The birth of tragedy,
1888).

The Birth of Tragedy, while in the pre-Socrates there was a unity between thought and life, the development of Socratic philosophy brought about the progressive degeneration of these two dimensions. Socrates proposed the task of judging life, opposing it to higher values, mediating it by them, imposing limits and condemning it:

Socrates, the dialectical hero in Platonic drama, reminds us of the kindred nature of the Euripidean hero, who has to defend his actions by arguments and counter- arguments, and thereby so often runs the risk of forfeiting our tragic pity ; for who could mistake the optimistic element in the essence of dialectics, which celebrates a jubilee in every conclusion, and can breathe only in cool clearness and consciousness : the optimistic element, which, having once forced its way into tragedy, must gradually overgrow its Dionysian regions, and necessarily impel it to self-destruction even to the death-leap into the bourgeois drama. Let us but realise the consequences of the Socratic maxims: Virtue is knowledge; man only sins from ignorance; he who is virtuous is happy: these three fundamental forms of optimism involve the death of tragedy (NIETZSCHE, S14, 1872).

While the Greeks interpreted the Greek tragedy as characteristic of the mystical knowledge of the unity of life and death, Socrates interpreted the tragic art as something irrational that has causeless effects and should be ignored. Because he was not useful, he reinforced the argument that they should abstain from such unworthy emotions as philosophers. It is not least that according to Socrates, the art of tragedy deviates men from the path of truth, thus a single and beautiful work obeying reason. Nietzsche discusses in The Birth of Tragedy this conception was established a dialectical opposition between Socrates and Dionysus. Because: 
While in all productive men it is instinct which is the creatively affirmative force, consciousness only comporting itself critically and dissuasively; with Socrates it is instinct which becomes critic, it is consciousness which becomes creator a perfect monstrosity per defectum! (NIETZSCHE, S13, 1872).

Viesenteir (2010) when analyzing the concept of reason in Nietzsche points out that Socrates was defined as decadent for elucidating a process that culminated in the perversion of reason itself. The understanding of the perversion goes back to when Socrates recognizes among the Athenians precisely the same process that characterizes it par excellence: dissolution, disintegration, corruption. The rampant and the confessed anarchy of the instincts, which in turn, are properly indications of decadent.

In Socrates, the instinctive wisdom of tragic art was lost, leaving only the logical-rational aspect. With this, the era of reason was inaugurated, which opposed the mystical meaning of the whole tradition of tragedy, establishing the beginnings of the dichotomy of reason and emotion (FEREZ, 1999).

If duality begins in the Greek period, it continues to perpetuate whole history of Western philosophy, until it reaches the assumptions of theories of knowledge based on scientific thought. For Nietzsche dualism manifests itself:

Our whole modern world is entangled in the meshes of Alexandrine culture, and recognizes as its ideal the theorist equipped with the most potent means of knowledge, and labouring in the service of science, of whom the archetype and progenitor is Socrates (NIETZSCHE, S18, 1872).

Nietzsche in The Gay Science explores the features of dichotomy inherited from Socrates and manifests in contemporary assumptions, especially from positivist epistemology. In directing criticism of the propositions that underpin the theory of knowledge, it denounces the ideals of impersonality, inalterability, as if dimensions negate impulses in reason.

Thus the strength of knowledge lies not in its degree of truth, but in its age, its embeddedness, its character as a condition of life. Where life and knowledge seem to contradict each other, there was never any serious fight to begin with; denial and doubt were simply considered madness. Those exceptional thinkers, like the Eleatics, who still posited and clung to the opposites of the natural errors, believed in the possibility of also living this opposite: they invented the sage as the man of unchanged-ability, impersonality, universality of intuition, as one and all at the same time, with a special capacity for that inverted knowledge; they had the faith that their knowledge was at the same time the principle of life. But in order to be able to claim all this, they had to deceive themselves about their own state: they had fictitiously to attribute to themselves impersonality and duration without change; they had to misconstrue the nature of the knower, deny the force of impulses in knowledge, and generally conceive reason as a completely free, self-originated activity. They closed their eyes to the fact that they, too, had arrived at their propositions in opposition to what was considered valid or from a desire for tranquility or sole possession or sovereignty. (NIETZSCHE, S110, BOOK III, 1882). 
In Viesenteir's (2010) readings, Nietzsche's association between reason and decadence unfolds throughout modernity, adding a metaphysical value to its main epistemological categories. A stubborn attempt to overcome the transitory and all that is related to corporeality, the demand for "truth at all costs" will take more definite contours with the heightened moralism of the philosophers of knowledge.

The critiques of Nietzsche's thinking also opened space for reflections in the field of psychology and the unconscious as the subjective dimension of reason. It is not least that in The Gay Science, the author points out that to know is to understand also the impulses previously presented.

Conscious thinking is what presents to Nietzsche as one of the greatest fallacies of the philosopher who believes in the nature of knowing as a purely logical process.

Since only the ultimate reconciliation scenes and final accounts of this long process rise to consciousness, we suppose that intelligere must be something conciliatory, just, and good, something essentially opposed to the instincts, when in fact it is only a certain behaviour of the drives towards one another.

For the longest time, conscious thought was considered thought itself; only now does the truth dawn on us that by far the greatest part of our mind's activity proceeds unconscious and unfelt; but I think these drives which here fight each other know very well how to make themselves felt by and how to hurt each other. [...]Conscious thought, especially that of the philosopher, is the least vigorous and therefore also the relatively mildest and calmest type of thought; and thus precisely philosophers are most easily led astray about the nature of knowledge (NIETZSCHE, S333, BOOK IV, 1882).

Leiter (2017), analyzing Nietzsche's thought on the subject, points out that conscious thoughts have an epiphenomenon status in relation to unconscious psychology and agent physiology, which in turn refers to the psychophysical type to which each individual must be linked.

Nietzsche's point is that thoughts arise in consciousness without being wanted. This assumption is a critique of the Cartesian doctrine of 'I think therefore I am' which establishes a purism of reason.

For Leiter (2017), Nietzsche points out that there is something thinking that it does not follow that this something is "me", that is, that some object or agent is thinking; and it does not follow that the self exists. The remark is recorded in Beyond Good and Evil:

As far as the superstitions of the logicians are concerned: I will not stop emphasizing a tiny little fact that these superstitious men are loath to admit: that a thought comes when "it" wants, and not when "I" want. It is, therefore, a falsification of the facts to say that the subject "I" is the condition of the predicate "think." It thinks: but to say the "it" is just that famous old "I" - well that 
is just an assumption or opinion, to put it mildly, and by no means an "immediate certainty" (NIETZSCHE, S17, 1886).

Oleare (2011), in his work on affections and passions in Nietzsche, approaches interpretation by addressing that the ideas of freedom of will as an attribute of the rational-conscious subject presupposes that all action and thought derive from a choice, a desire. However, contrary to traditional metaphysics, Nietzsche considers that passions operate as hatred and revenge on the innocence of becoming, drives, instincts.

These prerogatives call into question the purity of a person's moral beliefs in psychophysical terms, in which moral judgments are symptoms and symbol languages that have revealed the process of physiological prosperity or decay, illustrating the symbiosis in reason and emotion.

In analyzing the affections in Espinosa and Nietzsche, Martins (2000) points out that traditional philosophy considers affection and reason as opposites, separating, to the extent of thought, the body of soul (or mind or psyche). However, what changes with Nietzsche is precisely its ontology.

For a better understanding of these relationships, we will address the next topics to illustrate that the dimensions of reason and emotion are not only interconnected, but mutually influential in the constitution of philosophical thinking.

\section{The influences of emotions on the constitution of reason/morals}

Assuming that there is no dualism between reason and emotion, Nietzsche uses Socrates' analyzes of morality, Christianity, and nihilism to illustrate the emotions implicit in the formation of reason. In this sense, he mentions that Socrates defines his philosophy based on the motto "know thyself". The philosopher presented himself as the one who knew nothing when visiting and debating with the Greek citizens. However, he found that none of them had the right and sure understanding. But for Nietzsche, paradoxically on instinct and with an attitude of contempt and haughtiness, Socrates condemned current art and tried to correct it by creating his own metaphysics: 
The most decisive word, however, for this new and unprecedented esteem of knowledge and insight was spoken by Socrates when he found that he was the only one who acknowledged to himself that he knew nothing; while in his critical pilgrimage through Athens, and calling on the greatest statesmen, orators, poets, and artists, he discovered everywhere the conceit of knowledge. He perceived, to his astonishment, that all these celebrities were without a proper and accurate insight, even with regard to their own callings, and practiced them only by instinct. With this phrase we touch upon the heart and core of the Socratic tendency. wherever Socratism turns its searching eyes it beholds the lack of insight and the power of illusion; and from this lack infers the inner perversity and objection ableness of existing conditions. From this point onwards, Socrates believed that he was called upon to, correct existence ; and, with an air of disregard and superiority, as the precursor of an altogether different culture, art, and morality, he enters singlehanded into a world, of which, if we reverently touched the hem, we should count it our greatest happiness (NIETZSCHE, S13, 1872).

Nietzsche's criticism that led to the formation of Socrates's philosophy is based not only on instincts prior to the creation of reason, but also on a possible contradiction present in the passage of the Delphic Oracle, in which it is the demon of Socrates who makes him question about himself, about his ignorance. An inner demon, something unreasonable is the stimulus, the impulse for the constitution of a reason which for Nietzsche is emotion itself, the Dionysian phenomenon which Socrates tried to deny:

A key to the character of Socrates is presented to us by the surprising phenomenon designated as the "daimonion" of Socrates. In special circumstances, when his gigantic intellect began to stagger, he got a secure support in the utter ances of a divine voice which then spake to him. This voice, whenever it comes, always dissuades. [...] And we do indeed observe here a monstrous defectus of all mystical aptitude, so that Socrates might be designated as the specific non-mystic; in whom the logical nature is developed, through a superfoetation, to the same excess as instinctive wisdom is developed in the mystic. On the other hand, however, the logical instinct which appeared in Socrates was absolutely prohibited from turning against itself; in its unchecked flow it manifests a native power such as we meet with, to our shocking surprise, only among the very greatest instinctive forces (NIETZSCHE, S13, 1872).

The influences of the "devil", the instincts on the motivations of Socrates' dialectic illustrate the emotions in the process of abstraction, just as Nietzsche in Twilight of Idols addresses a feeling of revenge, of revolt over the Greek nobility, by proposing metaphysics against Socrates' opponents:

Is Socrates' irony an expression of revolt? Of the rabble's ressentiment? Does he, as one of the oppressed, relish his own ferocity in the knife-thrusts of the syllogism? Does he take revenge on the nobles whom he fascinates? As a dialectician, one has a merciless instrument at hand; one can play the tyrant with it; one compromises by conquering. The dialectician lays on his opponent the burden of proving that he is not an idiot: he infuriates, and at the same time he paralyzes. The dialectician disempowers the intellect of his opponent. What? Is dialectic just a form of revenge in Socrates? (NIETZSCHE, S7, The Problem of Socrates, 1889).

But Socrates surmised even more. He saw past his noble Athenians; he grasped that his case, his idiosyncratic case, already wasn't exceptional. The same kind of degeneration was silently preparing itself everywhere: the old Athens was coming to an end. And Socrates understood that all the world had need of his means, his cure, his personal device for self-preservation. Everywhere, the instincts were in anarchy; everywhere, people were five steps away from excess; the monstrum in animo was the general threat. "The drives want to play the tyrant; we have to invent a stronger countertyrant" (NIETZSCHE, S9, The Problem of Socrates, 1889). 
The venom of Socratic resentment, its vices, wounds, and all plebeianism are expressed through rebellion against the ancient Hellenic, whose revenge is the "over the affection of the logical", the dialectic as revenge. The cure for the dissolution and anarchy of the instincts will be recorded under the rubric of rationality, which in turn is the invention of the even stronger "contractor" mechanism of Socratic that must oppose the tyranny of instincts (VIESENTEIR, 2010).

Nietzsche's arguments are not limited to Socrates' criticism. In the book On the Genealogy of Moral, he points out that Christian morality, materialized in a systematized set of arguments, of reason, however, has as its background a feeling, an emotion that interferes and motivates the constitution of moral values.

According to Nietzsche, Christianity conceives the earthly world as a valley of tears, as opposed to the world of eternal happiness. This metaphysics establishes on Platonic influence two worlds: the sensible, as provisional, inauthentic, and apparent, and that of light, of ideas, as authentic, true (FEREZ, 1999).

But behind this moral, Nietzsche argues that dogmas and beliefs are what allow weak and slave consciousness to escape life, imposing resignation and renunciation as virtues. Moreover, being the slaves and the losers of life who created this morality, they did so because they could not share in the values of their masters, thus establishing a myth of soul salvation and creating the idea of sin, because they could not participate in the same way satisfaction of life's instincts.

The hatred of all that is human, all that is matter, the fear of the senses, the desire to escape everything that appears, the will to refuse, to hostility to life, has as its motivation previous feelings, which interfered with constitution of morals (FEREZ, 1999).

For Nietzsche On the genealogy of Morality, however, this creation is based on the feeling of revenge, in which the slave seeks a way to dominate, to feel superior. Thus, in the idea of creating moral values close to the reality of the poor and slaves, the power relationship can be inverted based on the formula you are evil, I am good, the weak becomes strong, the lowliness becomes nobility.

The beginning of the slaves' revolt in morality occurs when ressentiment itself turns creative and gives birth to values: the ressentiment of those beings who, denied the proper response of action, compensate for it only with imaginary revenge. Whereas all noble morality grows out of a triumphant saying 'yes' to itself, slave morality says 'no' on principle to everything that is 'outside', 
'other', 'non-self ': and this 'no' is its creative deed. This reversal of the evaluating glance - this essential orientation to the outside instead of back onto itself - is a feature of ressentiment: in order to come about, slave morality first has to have an opposing, external world, it needs, physiologically speaking, external stimuli in order to act at all, - its action is basically a reaction (NIETZSCHE, S10, First essay, 1887).

Moreira (2009), studying Nietzsche's concept of resentment morality, points out that resentment is self-poisoning conditioned by feelings such as hatred, rancor, envy and revenge, which offer Nietzsche the appropriate language to expose his perspective in the field of morals.

Resentment serves to highlight that man who has no strength to react to life's unforeseen and hardships and who, too, cannot digest the bad feelings, those harmful, poisonous feelings produced by his inability to perform the reaction, that of acts. Thus, the individual begins to manifest a psychological imbalance driven by an imaginary revenge, to live in function of an outside, another, a non-self, and this is not his creative act, since this inversion of the gaze that establishes values - this need to be directed outwards rather than towards oneself is something of resentment.

Resentful man turns his own weakness into strength, which in turn is regarded as a virtue. He attributes positive values to renunciation, altruism, disinterest, and compassion. Unable to act in a world where power conflict prevails, he prefers to create another world where he will be privileged and prominent. The man of resentment transfigures weakness into kindness, submission into humility, cowardice into resignation, the desire for revenge in divine justice.

However, if Nietzsche presented himself as a critic of Christianity as a herd morale, he did not fail to direct his analyzes of nihilism in The Will of Power. For him the influences of emotions on the rational constitution also manifest themselves, however marked by a change of a religious belief in a new conviction, in the immorality of nature, in the meaninglessness:

\begin{abstract}
Extreme positions are not succeeded by moderate ones but by extreme positions of the opposite kind. Thus the belief in the absolute immorality of nature, in aim- and meaninglessness, is the psychologically necessary affect once the belief in God and an essentially moral order becomes untenable. Nihilism appears at that point, not that the displeasure at existence has become greater than before but because one has come to mistrust any "meaning" in suffering, indeed in existence. One interpretation has collapsed; but because it was considered the interpretation it now seems as if there were no meaning at all in existence, as if everything were in vain (NIETZSCHE, S55, BOOK I, June, 1887).
\end{abstract}

Moreira (2009) discusses that nihilism expresses a fundamental aspect of human will: the fear of emptiness, of nothingness, the need for a goal of an ultimate 
end. That is why man prefers nothingness to nothingness. This means that ascetic ideals, as a negation of life and its fundamentals, are paradoxically intrinsic to life and the world they deny.

The influences of emotions on reason through the constitution of morality in Socrates, Christianity, and nihilism come close to harsh criticism of the concept of truth, good and evil, as categories marked by instincts, emotions that interfere with these rational dimensions.

Nietzsche in The Dawn of the Day points out that while animals learn to master or disguise themselves to adapt to the environment, men create the concepts and senses of truth to deal with their feelings of insecurity, survival or even escape enemies. No wonder Socratic virtues present themselves as an influence of men's impulses for survival:

\begin{abstract}
The rules insisted upon in polite society, such, for example, as the avoidance of everything ridiculous, fantastic, presumptuous; the suppression of one's virtues just as much as of one's most violent desires, the instant bringing of one's self down to the general level, submitting one's self to etiquette and self-depreciation: all this, generally speaking, is to be found, as a social morality, even in the lowest scale of the animal world-and it is only in this low scale that we see the innermost plan of all these amiable precautionary regulations: one wishes to escape from one's pursuers and to be aided in the search for plunder. Hence animals learn to control and to disguise themselves to such an extent that some of them can even adapt the colour of their bodies to that of their surroundings. It is in this way that an individual conceals himself behind the universality of the generic term "man" or "society," or adapts and attaches himself to princes, castes, political parties, current opinions of the time, or his surroundings: and we may easily find the animal equivalent of all those subtle means of making ourselves happy, thankful, powerful, and fascinating. Even that sense of truth, which is at bottom merely the sense of security, is possessed by man in common with the animals: we do not wish to be deceived by others or by ourselves; we hear with some suspicion the promptings of our own passions, we control ourselves and remain on the watch against ourselves. The beginnings of justice, like those of wisdom-in short, everything which we know as the Socratic virtues-are of an animal nature: a consequence of those instincts which teach us to search for food and to avoid our enemies. If we remember that the higher man has merely raised and refined himself in the quality of his food and in the conception of what is contrary to his nature, it may not be going too far to describe the entire moral phenomenon as of an animal origin. (NIETZSCHE, S26, BOOK I, 1881).
\end{abstract}

Similarly, Nietzsche in the book On the Truth and Lying in an extra-moral sense, points out that the influences of emotion on reason not only occur in the attempt to create concepts, moral values, but it also expresses an earlier emotion, based on the influence of feelings of fear and intuitions. For him, the creation of truth is the manifestation of man's impulses in reason:

What is truth? A mobile army of metaphors, metonyms, anthropomorphisms, in short, a sum of human relations which were poetically and rhetorically heightened, transferred, and adorned, and after long use seem solid, canonical, and binding to a nation. [...] We still do not know where the desire for truth originates; for until now we have heard only of the obligation which society, in order to exist, imposes: to be truthful, i.e., to use the customary metaphors, or in moral terms, the obligation to lie according to an established convention, to lie collectively in a style that is mandatory 
for everyone. Now, of course, man forgets that this is his situation; so he lies in the designated manner unconsciously and according to centuries-old habits - and precisely by this unconsciousness, by this for-getting, he arrives at his sense of truth. The sense of being obliged to call one thing "red," another "cold," a third one "mute," gives rise to a moral feeling with respect to truth. By contrast with the liar, whom no one trusts, whom all ostracize, man proves for himself the honorableness, the familiarity, the usefulness of truth. As a "rational" being, he now puts his actions under the rule of abstractions; he no longer lets himself be carried away by sudden impressions, by intuitions (NIETZSCHE, S1, 1873).

Interpretations in Nietzsche's works are also illustrated by Araldi (2015), when analyzing the connection between passions and moral values. The author points out that for Nietzsche fear is the father of morality. Fear of uncertainty, of other men, of nature, causes primitive man to submit to the rules of a certain higher authority. In developing to this argument, he concludes that the common quality of all passions, the impulse, the will to exercise power, it is what results in the creation of moral values in society.

\section{Reason and morals in the complexion of emotions}

In the previous two topics, arguments have been presented in Nietzsche that establishes a deconstruction of the dichotomy, as well as illustrating the influence of emotions on the moral values of a particular thought or philosopher. However, Nietzsche does not necessarily establish greater weight for emotions as a determining dimension of reason. For him, this process can occur in a two-way street, where reason, moral values, also influence emotions.

Note the prerogative in The Dawn of the Day, specifically in sentences S35 (feelings and their descent from judgments) and S38 (impulses transformed by moral judgments) (NIETZSCHE, BOOK I, 1881), which present in the titles the idea that moral judgments interfere with feelings and impulses.

Nietzsche discusses that to rely on feelings, on emotions, it is not to understand that in their constitution there are assumptions of value judgments that condition feelings:

Trust in your feelings! But feelings comprise nothing final, original; feelings are based upon the judgments and valuations which are transmitted to us in the shape of feelings (inclinations, dislikes). The inspiration which springs from a feeling is the grandchild of a judgment-often an erroneous judgment!-and certainly not one's own judgment! Trusting in our feelings simply means obeying our grandfather and grandmother more than the gods within ourselves: our reason and experience (NIETZSCHE, AURORA, S35, BOOK I, 1881). 
For him, moral judgments transform impulses, at the moment, when man comes into contact with society, with present values. Before that, the impulses do not have a feeling of good or bad, pleasure or displeasure:

In other words, this instinct will fall under the influence of either a good conscience or a bad one! In itself, like every instinct, it does not possess either this or indeed any other moral character and name, or even a definite accompanying feeling of pleasure or displeasure; it does not acquire all these qualities as its second nature until it comes into contact with impulses which have already been baptized as good and evil, or has been recognized as the attribute of beings already weighed and valued by the people from a moral point of view (NIETZSCHE, S38, BOOK I, 1881).

However, when the same impulse develops in the painful feeling of censorship that custom has imposed or in the pleasant feeling of humility, as Nietzsche quotes, the Christian thus clings to a good or bad conscience. To illustrate the constitution of judgments in emotions, Nietzsche cites the divergences between manifestations of envy and hope in ancient Greeks and contemporary societies, as well as the wrath among the Jews of early Christianity and nineteenth-century society. While envy was characterized as a normal, valuing aspect of Greek culture, hope was a limiting, illusory thing for people who believed in the cosmos. These two emotions change with modern societies, reversing meaning by moral and mainly JudeoChristian influences.

\begin{abstract}
The ancient conception of envy differed entirely from ours. Hesiod reckons it among the qualities of the good, benevolent Eris, and it was not considered as offensive to attribute some kind of envy even to the gods. This is easy to understand in a state of things inspired mainly by emulation, but emulation was looked upon as good, and valued accordingly. The Greeks were likewise different from us in the value they set upon hope: they conceived it as blind and deceitful. Hesiod in one of his poems has made a strong reference to it-a reference so strong, indeed, that no modern commentator has quite understood it; for it runs contrary to the modern mind, which has learnt from Christianity to look upon hope as a virtue. The Jews, again, took a different view of anger from that held by us, and sanctified it: hence they have placed the sombre majesty of the wrathful man at an elevation so high that a European cannot conceive it. They moulded their wrathful and holy Jehovah after the images of their wrathful and holy prophets. Compared with them, all the Europeans who have exhibited the greatest wrath are, so to speak, only second-hand creatures (NIETZSCHE, S38, BOOK I, 1881).
\end{abstract}

In addition to the elucidated examples, Nietzsche makes use of the distinctions between the conception of guilt and unhappiness in the Greeks and Christianity. For him, these differences illustrate how value judgments interfere with emotions, as they also change historically:

Misfortune and guilt: these two things have been put on one scale by Christianity; so that, when the misfortune which follows a fault is a serious one, this fault is always judged accordingly to be a very heinous one. But this was not the valuation of antiquity, and that is why Greek tragedy-in which misfortune and punishment are discussed at length, and yet in another sense-forms part of the great liberators of the mind to an extent which even the ancients themselves could not realise. They remained ingenuous enough not to set up an "adequate relation" between guilt and 
misfortune. The guilt of their tragic heroes is, indeed, the little pebble that makes them stumble, and on which account they sometimes happen to break an arm or knock out an eye. Upon this the feeling of antiquity made the comment, "Well, he should have gone his way with more caution and less pride." It was reserved for Christianity, however, to say: "Here we have a great misfortune, and behind this great misfortune there must lie a great fault, an equally serious fault, though we cannot clearly see it! If, wretched man, you do not feel it, it is because your heart is hardenedand worse than this will happen to you!"

Besides this, antiquity could point to examples of real misfortunes, misfortunes that were pure and innocent; it was only with the advent of Christianity that all punishment became well-merited punishment (NIETZSCHE, S78, BOOK I, 1881).

Oleare (2011) when dealing with the concept of good and virtue On the Genealogy of Morality, while for the warrior/aristocratic the good was value attributed to characteristics such as nobility, beauty and happiness, from the spiritual/religious good becomes quality of the weak, low, pale, poor, miserable, pious, unfortunate.

In Nietzsche's Antichrist, the concept of virtue based on the morals of slaves becomes kindness in the Judeo-Christian world. Virtue becomes the escape from the passions, taken as temptations. Seen from the moral slave, strong is the blessed, who denies the force of his affections in obedience to gregarious norms allegedly integrated with an eternal transcendence (OLEARE, 2011).

Another reference between morals and emotions is elucidated in The Will to Power. Nietzsche points out that morality protected the oppressed men from desperate bitterness against existence. The moral that taught the violated to hate and despise the will to power in the dominant is the same that enables the belief in the right of their contempt. The following passage makes an analogy to Christianity, recording morality a role in interfering with emotions:

\begin{abstract}
It was morality that protected life against despair and the leap into nothing, among men and classes who were violated and oppressed by men: for it is the experience of being powerless against men, not against nature, that generates the most desperate embitterment against existence. Morality treated the violent despots, the doers of violence, the "masters" in general as the enemies against whom the common man must be protected, which means first of all encouraged and strengthened. Morality consequently taught men to hate and despise most profoundly what is the basic character trait of those who rule: their will to power. To abolish, deny, and dissolve this morality-that would mean looking at the best-hated drive with an opposite feeling and valuation. If the suffering and oppressed lost the faith that they have the right to despise the will to power, they would enter the phase of hopeless despair. This would be the case if this trait were essential to life and it could be shown that even in this will to morality this very "will to power" were hidden, and even this hatred and contempt were still a will to power. The oppressed would come to see that they were on the same plain with the oppressors, without prerogative, without higher rank (NIETZSCHE, S55, BOOK I, June, 1887).
\end{abstract}

The similarities of interpretations are also stated as presuppositions in Araldi (2015), by stating that Nietzsche would agree that emotions, impulses and feelings 
determine moral judgments, but also that, in this complex and reversible relationship, impulses are transformed by moral judgments.

Citing the work The Dawn of the Day, Araldi (2015), corroborates the hypothesis that the aphorism of the title "impulses transformed by moral judgments" (NIETZSCHE, S38, BOOK I, 1881), exposes the decisive transmutations of the original impulses of the human being, until they assume a different conformation, a second nature, which illustrates the double movement of reason and emotion.

\section{Conclusion}

Nietzsche's contributions to reason and emotion establish an ontology/genealogy of reality, where every event of reality takes place in the expression of degrees of reason and emotion, good and evil, light and shadow, truth and nontruth. Do not absolutize one pole over the other, they do not disconnect (OLEARE, 2011). The dynamics manifested to Nietzsche as a way of life, opens spaces for rethinking ethical dimensions not only rational and objective, but, interfered by emotions and conditioned by value judgments.

This explains Leiter's (2017) conclusion in Nietzsche as the "first" psychologist for anticipating in centuries the empirical psychology. If studies in the field of psychology and neuroscience today bring inferences from explanations of physiology in the rational, Nietzsche's studies pointed to these hypotheses earlier, albeit by purely logical and rational means.

Innovations in Nietzsche's thinking thus contribute to dialogue with the recent themes of emotion theories, as well as to counteract the ethical rationality superimposed on affect, which has reduced emotions to dimensions that merely reflect our incompleteness and imperfection (ALMADA, 2010).

Nietzsche, by bringing out emotions, instincts as an agenda in the field of philosophy, emphasizes in his own words that the theme enables us to reflect on feeling as well as to change feeling. This process involves learning to unlearn, a change of thinking and emotion that seems new to the agenda of current philosophical thinking. 
I deny morality in the same way as I deny alchemy, i.e. I deny its hypotheses; but I do not deny that there have been alchemists who believed in these hypotheses and based their actions upon them. I also deny immorality-not that innumerable people feel immoral, but that there is any true reason why they should feel so. I should not, of course, deny-unless I were a fool-that many actions which are called immoral should be avoided and resisted; and in the same way that many which are called moral should be performed and encouraged; but I hold that in both cases these actions should be performed from motives other than those which have prevailed up to the present time. We must learn anew in order that at last, perhaps very late in the day, we may be able to do something more: feel anew (NIETZSCHE, S103, BOOK II,1881).

To "know", to study the emotions is to present an intuitive knowledge of the relations that are established with and in the world in which it is constituted. Accepting the world and emotions rather than denying for a rational imaginary world or values deemed necessary may be the relevance of considering emotions in the constitution of morals and ethics. However, this does not imply reproducing it on a rational bias. This is not a separation of subject and object (which would already be a contradiction to the critique of dualism). But to consider that emotions are in the present becoming, so that we must thrill along with our knowledge, as well as knowing along with our affections (MARTINS, 2000).

As a limitation of the essay it is noteworthy that despite the vast literature on theories of emotions, we chose not to draw ontological distinctions, and draw differences or similarities between concepts of emotions. Moreover, in Nietzsche's own work the author did not necessarily use the etymology emotions, but related terminologies, such as: affections, passions, feelings, resentments. By not entering into establishing singularities, future studies may contribute to the proper etymological deepening.

Finally, if Nietzsche has made his philosophy an art of interpretation and analysis, by placing multiple provocations against the values given in our society through his hammer philosophy, it is possible to conclude with some initial and provocative reflections, in order to advance on the Nietzsche's thought. We ask: (a) If emotions are conditioned and condition reason, what feelings in Nietzsche led to his critique of reason and morality? (b) Is contempt for the hypertrophy of reason a feeling of revenge, of resentment in the author? (c) Didn't Nietzsche deconstruct the foundations of science and traditional Western philosophy centered on the preponderance of reason, the same reason as a method of criticism? 


\section{References}

ALMADA, L. F. A neurociência afetiva como orientação filosófica: por uma ressignificação neurofilosófica do papel das emoções na estruturação do comportamento. Educação e filosofia, Uberlândia, v. 25, n. 49, p. 201-226, jan./jun. 2011.

ALMADA, L. F. As relações neurais de interação e integração entre raciocínio moral e emoções: um diálogo das neurociências com as éticas contemporâneas. Ethi@@ Florianópolis, v. 9, n. 1 p. 89-109, 2010.

ALVES, M. A. S. Are emotions necessary and sufficient for making moral judgments? Ethi@@Florianópolis, v. 12,n. 1, jul., p.113-116, 2013

ARALDI, C. L. Nietzsche, Hume e a naturalização das paixões. C Dissertatio, v. suplementar, dez., 2015.

ARAUJO, M. F. S. A emoção e a construção do social. Política e Trabalho, v. 17, set., 2001.

BORGES, M. L. Emoções e motivação moral: Prinz versus Kant. Conjectura: Filos. Educ., Caxias do Sul, v. 22, n. especial, p. 59-67, 2017.

COSTA, A. J. A.; PASCUAL, J. G. Análise sobre as emoções no livro Teoría de las emociones (Vigotski). Psicologia \& Sociedade, v. 24, n. 3, p. 628-637, 2012.

FEREZ, O, C. Nietzsche. Obras Incompletas. São Paulo: Nova Cultural, 1999.

GRAY, J.; BRAVER, T.; RAICHLE, M. Integration of emotion and cognition in the lateral prefrontal cortex. PNAS, New York, v. 99, n. 6, p. 4115-4120, 2002.

LEITER, B. A teoria nietzschiana da vontade. Cad. Nietzsche, Guarulhos/Porto Seguro, v. 38, n. 3, p. 17-49, set./dez. 2017.

MARIN, C.; SILVEIRA, M. M. Intersecções entre ciência e filosofia. Conjectura: Filos. Educ, v. 22, n. especial, 2017.

MARTINS, A. Nietzsche, Espinosa, O acaso e os afetos. Encontros entre o trágico e o conhecimento intuitivo. O que nos faz pensar, n. 14, ago. 2000.

MOREIRA, R. Nietəsche, Genealogia e Transvaloração: Uma crítica ao cristianismo enquanto uma moral do ressentido. Dissertação (Mestrado em Filosofia) — Instituto de Cultura e Arte, Universidade Federal do Ceará. Fortaleza, 2009.

NIETZSCHE, F. W. Beyond Good and Evil: Prelude to a Philosophy of the future (1886). Translated by Judith Norman. Cambridge: University Press, 2001.

NIETZSCHE, F. W. The Dawn Of Day (1881). Translated by John Kennedy. New York: Macmillan Company, 1911.

NIETZSCHE, F. W. Twilight of the Idols (1888-1889). Translated by Richard Polt. Indianapolis: Hackett Publishing Company, 1997. 
NIETZSCHE, F. W. Ecce Homo (1888-1908). Translated by Anthony Ludovici. London: Edinburgh, 1911.

NIETZSCHE, F. W. The Gay Science (1882-1887). Translated by Josefine Nauckhoff. Cambridge: University Press, 2001.

NIETZSCHE, F. W. The Antichrist (1888). Translated by Henry Mencken. Adelaide: University of Adelaide, 2016.

NIETZSCHE, F. W. The birth of tragedy or Hellenism and Pessimism (1872). The complete Works. Translated by Haussmann, W. New York: Macmillan company, 1909.

NIETZSCHE, F. W. On the Genealogy of Morality (1887). Translated by Carol Diethe. Cambridge: University Press, 2006.

NIETZSCHE, F. W. On the true and lying in an extra-moral sense (1873). Translated by Sander Gilman. Oxford: University Press, 1989.

NIETZSCHE, F. W. The Will to Power (1881-1966). Translated by Walter Kaufmann. New York: Vintage Books, 1968.

OLEARE, M. A. Paixões Transvaloradas. O primado do afeto na filosofia de Nietzsche. Dissertação (Mestrado em Filosofia) - Centro de Ciências Humanas e Naturais, Universidade Federal do Espírito Santo, Vitória, 2011.

VIESENTEIR, J. L. Fisio-psicologia e linguagem em Nietzsche: um viés de crítica à racionalidade. Princípios: Revista de Filosofia, Natal, v. 17, n. 27, jan./jun, p. 52-74, 2010. 